\title{
Britannia
}

http://journals.cambridge.org/BRI

Additional services for Britannia:

BRITANNIA

Email alerts: $\underline{\text { Click here }}$

Subscriptions: Click here

Commercial reprints: Click here

Terms of use : Click here

\section{The Making of Britain's First Urban Landscapes: The Case of Late Iron Age and Roman Essex}

Martin Pitts and Dominic Perring

Britannia / Volume 37 / November 2006, pp 189 - 212

DOI: 10.3815/000000006784016585, Published online: 01 March 2010

Link to this article: http://journals.cambridge.org/abstract S0068113X00001781

How to cite this article:

Martin Pitts and Dominic Perring (2006). The Making of Britain's First Urban Landscapes: The Case of Late Iron Age and Roman Essex. Britannia, 37, pp 189-212 doi:10.3815/000000006784016585

Request Permissions : $\underline{\text { Click here }}$ 


\title{
The Making of Britain's First Urban Landscapes: The Case of Late Iron Age and Roman Essex
}

\author{
By MARTIN PITTS and DOMINIC PERRING
}

$\mathrm{T}$ This paper presents preliminary results from research into the early urbanisation of Southern Britain. The purpose of the research is to use the evidence of material culture to describe ways in which the creation of cities may — or may not — have influenced social and economic change within the broader landscape.

The paper is set out in two main parts. The introduction summarises our research agenda, which is concerned with where and when cities first appeared in Britain, and how archaeological data can be interrogated to describe the economic and social relations that sustained them. ${ }^{1} \mathrm{We}$ suggest that the density and intensity of archaeological research in South-East England adds vital new data to the study of urban process, and allows us to develop and test a range of new models. This leads us to focus on the evidence of late Iron Age and early Roman Essex. The second part of this study shows how analysis of published pottery assemblages from sites in Essex allows us to address some of the questions raised. ${ }^{2}$ This section introduces important new information on the contrasting social practices that characterised different urban communities. In our concluding discussion we discuss some of the problems that we still have to address in describing the economic basis of early urban society in Britain.

\section{INTRODUCTION}

The issue of why towns are created and how they contribute to social change remains at the forefront of research within a range of different disciplines. ${ }^{3}$ Some aspects of the urban debate, amongst both geographers and social historians, remain poorly informed by the different perspective that the study of past material culture has to offer. There is continued emphasis on regarding urbanism as being determined by economic goals and subject to economically rational forces. ${ }^{4}$ Recent archaeological research has taken a different direction, tending to eschew the study of urbanism per se..$^{5}$ This has instead focused on the ways that patterns of

1 This part of the paper is based on a research proposal 'Town and Country in Roman Essex: A Research Proposal. Assessment and Updated Project Design' submitted to English Heritage by Dominic Perring (November 2004).

2 This section draws on findings from $\mathrm{PhD}$ research undertaken by Martin Pitts (Pitts forthcoming).

3 See Perring 2002b, 9-11 for a discussion of the problem of how to define cities, towns, and other nucleated settlements. We follow Castells (1977) in holding that the distinctions that can be drawn are a product of changing perceptions and legal definitions. From an archaeological point of view, it is perhaps easier to build definitions of site status from the evidence of consumption, rather than study patterns of consumption according to mutable and subjective definitions of site type.

4 The influence of such models is witnessed in the importance sometimes accorded to the work of Jane Jacobs (1969), for an articulate deconstruction of which see Mieroop 1999, 24-6.

5 As Whittaker 1990. 
consumption and display - including those structured through cities - can be used to explore aspects of identity and power relations. Cities matter critically to both, since they were designed as seats of power, and were places where new communities elaborated new identities. They were consequently places where wealth was concentrated, transformed, and transmitted.

Much has been written about both the economic basis of the ancient city and its material manifestation, ${ }^{6}$ particularly in terms of the nature of the relationship between town and country. How did towns support themselves, and what impact did urbanisation have on the wider landscape? There is an assumed tension between the demands of urban appetites and the capacity of the surrounding countryside to meet such needs. There are also arguments over the extent to which urban markets and institutions provided services to the surrounding countryside. The relationship between town and country was the main theme of a recent survey of the potential of archaeological research to contribute to the study of urban hinterlands in England. ${ }^{7}$ In this paper we wish to take the research ambitions outlined in that report further, and to focus on the circumstances of Britain's first experience of cities.

\section{BRITAIN'S URBAN ORIGINS}

The study of Britain's urban origins has undergone something of a transformation in recent years. ${ }^{8}$ The history of imperial expansion, the architectural expression of Roman authority, and the selective adoption of 'Roman' patterns of consumption made it possible to describe settlement and culture in terms of 'Roman' impositions on a 'native' society, in which the conquest of A.D. 43 marked a clear watershed. Towns, in particular, were seen as the product of military-supported colonial foundations that were the immediate manifestation of the post-conquest settlement, and which provided a template for the subsequent urbanisation of the native cantons. ${ }^{9}$ This new pattern of urban settlement was seen as qualitatively different, and comparatively detached, from the indigenous experiment in central places characterised by the Iron Age oppida of Lowland Britain (FIG. 1). This model has, however, begun to unravel of late.

First, longer chronologies can now be described. Britain's urban origins can be placed within the context of political developments that preceded the Claudian conquest, and the character and basis of urban settlement can now be seen to have undergone a series of significant changes well into the second century A.D. if not beyond. Military impositions were not the prime catalyst for the emergence of urban society. It appears that élite society in Britain had its own interest in adopting urban strategies, within the context of an agenda that was only in part inspired by Rome. Secondly, we are now increasingly aware of the variable nature of the power dynamics that supported urban society. Different communities engaged differently with Rome, according to particular patterns of affiliation and patronage. ${ }^{10}$

Two particular regions witnessed the precocious development of kingdoms and cities within Britain. These have been described by Creighton as the Southern and Eastern Kingdoms. ${ }^{11}$ Partial political histories can be constructed for both of these territories, on the basis of kings and

For a review of arguments see Whittaker 1995 and Parkins 1997.

Perring 2002b, in particular ch. 5.

Fulford 2003; Creighton 2000; Hill 2001.

e.g. Webster 1988; Wacher 1995.

10 Mattingly 2004 reviews evidence for the heterogeneous ways in which Roman identities were expressed in Britain and shows how these differed regionally and according to the political basis of power. Mattingly's argument is expressed in terms of a native versus Roman dichotomy, but it could be argued that pre-Roman patterns of élite power - and the particular circumstances of immigrant military and colonial plantations - were more critical to the different trajectories taken than any interest in either embracing or rejecting Rome per se.

11 Creighton 2000. 


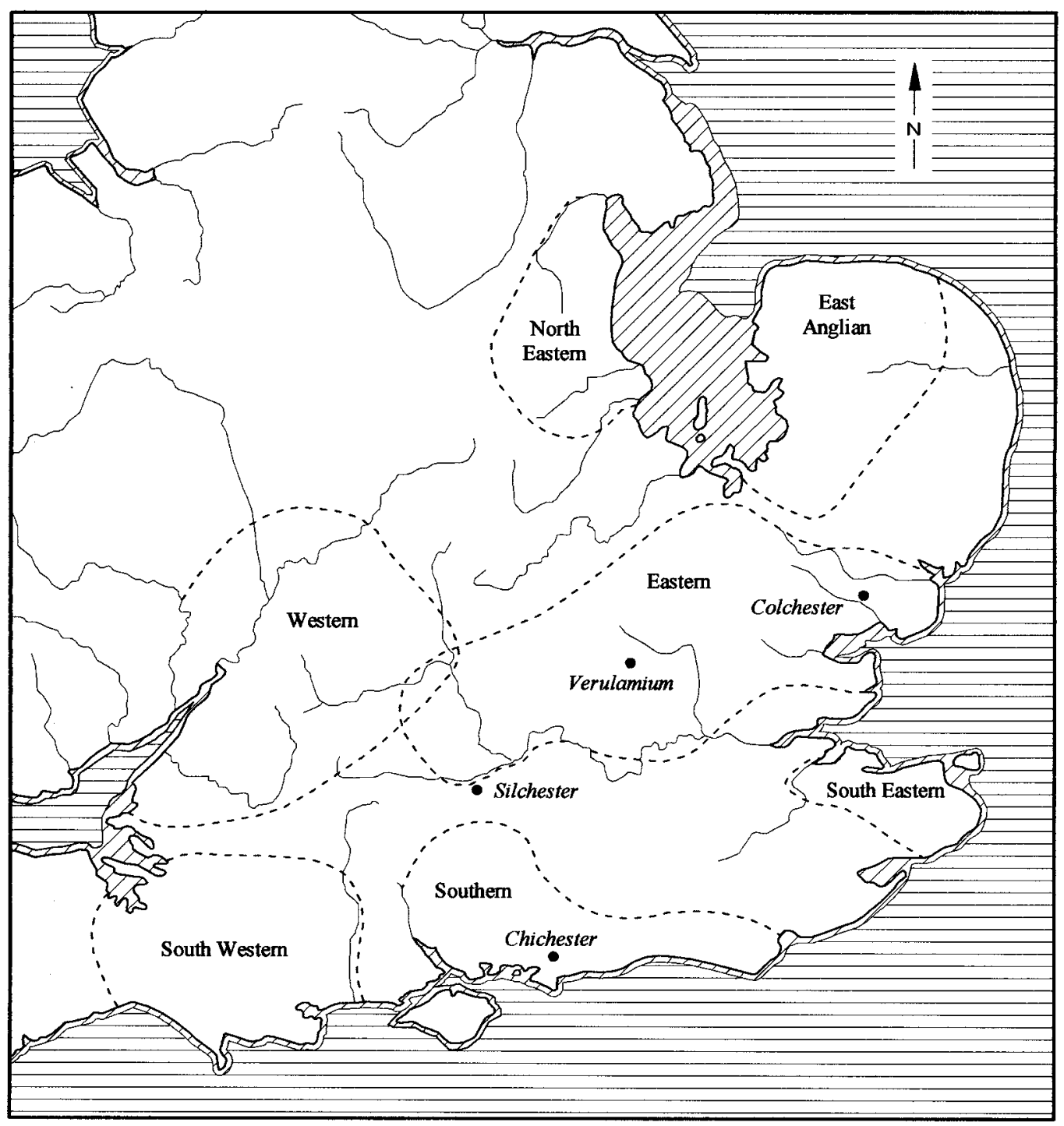

FIG. 1. Some of the main 'oppida' referred to in the text in the context of the regional coin series of Iron Age Britain (based closely on Creighton 2000 drawing on the work of Derek Allen).

rulers named on the coins issued within them. These coins also refer to the seats of power from which authority was obtained - the oppida that were later to become the sites of Roman cities. Due to the present lack of complete stratigraphic sequences for the main pre-Roman occupations at other oppida sites in southern Britain, we are presently better informed about the character and chronology of early urban development within the Southern ('Atrebatic') Kingdom because of the excavations conducted at Silchester by Fulford. ${ }^{12}$ These suggest that Silchester, located close 
to the northern boundary of the kingdom, was established as an urban plantation with a planned street grid sometime around $25-15$ B.C. ${ }^{13}$ This may have been an exceptional site, but other late Iron Age oppida within this region had clear urban aspirations. ${ }^{14}$

The Eastern Kingdom was dominated by Colchester, the capital of Cunobelin. ${ }^{15}$ Coins minted at Camulodunum, and bearing its name, show that this was the seat of kings, where a series of ditches and dykes gave form to a polyfocal landscape. This regal and ceremonial site became the principal target of the Claudian invasion, although in the wider region there were other important oppida where power was located and coins were minted. ${ }^{16}$

There is some disagreement within modern scholarship over whether the pre-Roman site of Camulodunum can properly be described as urban, but it appears to have been conceived of in urban terms at the time of its foundation. This is the argument presented by images deployed on the coins. Some of these seem to show Roman augurial ceremony, involving the curved staff or lituus, the very purpose of which was to define and describe urban status. ${ }^{17}$ This implies not just the copying of Roman orthogonal planning practices, but an educated engagement with Roman ideas about the sacred nature of urban political authority and the need to locate such power within ritually defined places. Perhaps more tenuously, it is also possible to regard the richlyfurnished grave in the Lexden tumulus as that of a Mediterranean-style hero-founder. ${ }^{18}$ Not only is the date of the burial consistent with the postulated construction of the Lexden Dyke (c. 25-10 B.C.), ${ }^{19}$ but parallels have been drawn between the appearance of the monument and Octavian's mausoleum in Rome, ${ }^{20}$ and the presence of certain finds suggests a dialogue with Roman ritual practice. ${ }^{21}$ Therefore, it seems likely that at Camulodunum this 'urban' status may have been the product of an episode of foundation in the Augustan period. ${ }^{22}$ This definition of the pre-Claudian oppidum as urban is essentially political and is not intended to carry any particular meaning with regard to the scale and function of the sites concerned.

After the capture of the city a Roman fort was established here, which was subsequently converted into a veteran colony. ${ }^{23}$ The Roman urban status of this later colonial foundation is more clearly asserted by both the documentary sources and the architecture of the site. The density of the archaeological deposits, structures, and finds associated with the colonial site is more evidently 'urban' in character. The early sequences of occupation here have been thoroughly studied in a series of excavations by the Colchester Archaeological Trust. ${ }^{24}$ The

13 This took place against the backdrop of a series of other Augustan changes in the use of wealth within the region, as indicated by the high-status burials at Welwyn Garden City and Lexden, new or re-ordered settlements as at Braughing and Elms Farm, and the re-coining of gold bullion.

14 There is a growing body of evidence, much of which awaits more detailed study, which suggests that Chichester was also an urban site in the late first century B.c. A series of dykes, the Chichester entrenchments, marked out a polyfocal landscape. Excavations of the earliest phases of the Roman city that later occupied a part of this site, have produced a significant amount of pre-conquest material and possible pre-conquest structures (Magilton 2003; Down 1989, 59-60; Down 1993; Down and Rule 1971, 143-7).

15 Crummy 1997, 15. Other central places within the Eastern Kingdom included Verulamium, probably founded in the period 20 B.C.-A.D. 10, and perhaps Canterbury. Fulford 2003 summarises recent work. For Verulamium, where the extent and character of the pre-Boudican settlement remains open to question, see Haselgrove and Millett 1997. For Canterbury see Williams 2003, 221: here too the status of the site is not clear.

16 Fulford 2003 summarises recent work.

17 Creighton 2000, 209; Rykwert 1976, 45-50.

18 Pitts forthcoming.

19 Hawkes and Crummy 1995, 175.

20 Creighton 2000, 187.

21 For example, Creighton $(2000,113)$ has noted the presence of a bronze cast featuring Roman sacrificial imagery (a tripod).

22 Creighton 2000.

23 Crummy 1997.

24 Crummy 1984; 1992 b. 
model that these suggest involves a fortress phase (A.D. 44-49) followed by the adaptation of the fortress to house the colonial foundation in $c$. A.D. 49; the latter was burnt to the ground in the revolt of A.D. 60/1.

Neither Camulodunum nor the fledgling Roman colony operated in isolation. In order to describe the relationship of this city to the surrounding countryside we must turn our attention to the wider settlement landscape. Cities operated within territories that can be defined in political, economic, and social terms. Traditionally, descriptions of the political geography of Roman Britain have been attempted from the available literary and epigraphic sources, which have closely influenced the archaeological descriptions offered by both Rivet and Wacher, in which the province was divided into a series of self-governing tribal communities, or civitates, each based on town and territory. ${ }^{25}$ In the case of the Eastern Kingdom we are informed of differences between a Catuvellaunian polity based on St Albans (Verulamium) and a Trinovantian one based on Colchester (Camulodunum). However, the civitates are not as robust a construct as this conventional wisdom has often decreed, being largely dependent on two literary sources - Ptolemy and the Ravenna cosmography. Ptolemy has no mention of capitals, whereas the Ravenna cosmography appears to be a very garbled source. ${ }^{26}$ It is therefore unsurprising that attempts to find archaeological differences between the tribal areas of the Trinovantes and the Catuvellauni on the basis of coin distributions have so far failed to convince. ${ }^{27}$ Indeed, most other archaeological correlates suggest a degree of uniformity within the territory of the Eastern Kingdom. ${ }^{28}$

Although we cannot identify material differences between Trinovantes and Catuvellauni, the boundaries of the Eastern Kingdom can be identified from a series of differences in the material culture. Sites on the frontier between the 'Icenian' polity to the north and the Eastern Kingdom to the south have been the subject of a series of recent excavations by the University of Cambridge Field Archaeology Unit. Differences in coin and ceramic use suggest that individual farmsteads within the frontier area were affiliated to one or other polity. ${ }^{29}$ These frontier areas were also characterised by an increased emphasis on ritual sites and practices. Votive deposits of metalwork in wet places, dating from both the Iron Age and Roman periods, are commonly found on the Essex-Suffolk borders, an area immediately beyond the northern boundary of the Eastern Kingdom. ${ }^{30}$

In sum, the descriptions that archaeology provides appear to define a bounded late Iron Age territory in South-East Britain that was culturally coherent, within which several putative cities were located. There is, as yet, no good reason to believe that this situation changed significantly after the Roman conquest. Indeed, similarities in the distribution patterns of different types of Iron Age coin and fourth-century Romano-British mosaics suggest that the cultural boundaries

25 Rivet 1964; Wacher 1995.

26 Here, as in so much of this paper, we are indebted to the critical acuity of John Creighton.

27 For different uses of the evidence of coin see De Jersey 2001 and Creighton 2000, 74-5.

28 These are the archaeological correlates — in particular pottery use and burial practice - that have been used to describe distributions of the Aylesford-Swarling cultural package: see Hill et al. 1999; see also Pitts 2005a. This polity equates with the core zone in Haselgrove's (1982) classic attempt to describe the cultural and political changes evident in pre-conquest Britain in terms of a dialogue between a 'Romanising' core and a native periphery. In this model the core zone exploited its immediate periphery for slaves and raw materials to fuel continental trade and the continued influx of imported prestige goods.

29 C. Evans 2003. It has been claimed that the slow pace of 'Romanisation' in the Icenian territories in the northern part of East Anglia was a consequence of confiscations and repressions that followed in the wake of the Boudiccan revolt. For a restrained version of this argument see Millett 1990, 100-1. A contrary view is possible. Differences in approach to the use of urban and Roman culture were present here before the Roman conquest, and persisted throughout the Roman period. This might, therefore, be another example of cultural continuity within the context of regional diversity.

30 A practice that appears to have continued into the late fourth century, if not beyond (Petts 2002). 
established prior to the Roman conquest remained current throughout the period of the Roman administration. ${ }^{31}$ With this in mind, we now turn to discuss the archaeological potential of the modern county of Essex, forming the north-eastern third of the Eastern Kingdom, as a suitable study area for further investigation.

\section{LATE IRON AGE TO ROMAN ESSEX AS A STUDY AREA}

Roman Essex holds a rather special place in the study of imperialism and its consequences. The Thames estuary was the setting that Conrad used to begin his novel The Heart of Darkness, in which parallels were drawn between the barbarisms of exploitation that followed the march of Rome's empire, with those that Conrad witnessed in the contemporary colonial adventure in Central Africa. Arguments about imperialism and cultural domination continue to make Roman archaeology an important field of research. The context in which this paper is written is, however, a very different one to that which inspired Conrad. Where Conrad saw an alien and incomprehensible world, opposed to that of civilised Rome, archaeologists prefer to see a sophisticated Iron Age society already in close dialogue with the Roman world. The archaeological landscape of Roman Essex has also become tantalisingly comprehensible, understandable but not understood. This is a place where further research is warranted.

The primary aim of the 'Town and Country in Roman Essex' project is to illuminate our understanding of the role of urbanism in processes of change in early Britain, particularly through the deployment of archaeological evidence to describe networks of socially- and economically-constructed relationships. In order to facilitate this, it is essential to transcend the methodological and conceptual hurdles preventing archaeologists looking beyond individual sites and towards broader research themes. Although it is widely recognised that sites need to be viewed within broader systems and landscapes, there is a tendency, encouraged by the sitespecific nature of commercial funding, to view each excavation as an end in itself. Often all that matters is a site narrative, describing a chronology of architectural change illustrated by catalogued archives of finds. Indeed, the prevailing forces in British archaeology are fostering a situation in which a wealth of data is not being utilised. As Hill recently observed in a review of the current state of research on Roman Britain, 'the lack of synthesis and analysis of the increasingly large number of excavations is a major problem'. ${ }^{32}$ There is an urgent need to move beyond the low-density mapping of landscapes and intense description of individual sites, and to draw on complex data from multiple finds assemblages and classes of material culture in describing different approaches to production and consumption.

Our research has entailed a detailed review of the potential of a range of archaeological assemblages obtained from fieldwork undertaken in and around Essex, building on work undertaken by the Colchester Archaeological Trust and Essex County Council at sites such as Colchester, Chelmsford, and Heybridge (FIG. 2). It can be argued that archaeological research into urban processes is best served by studying the networks of social and economic relationships that sustained complex hierarchies of settlement. One way of achieving this is by comparing changing patterns of consumption, as represented by archaeological finds, across different classes of settlement. Pottery is a key source of information in the study of such patterning, and its importance in describing patterns of supply and elucidating different marketing strategies has long been established. ${ }^{33}$ Evans' more recent work on Roman pottery in Northern Britain

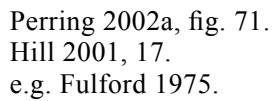




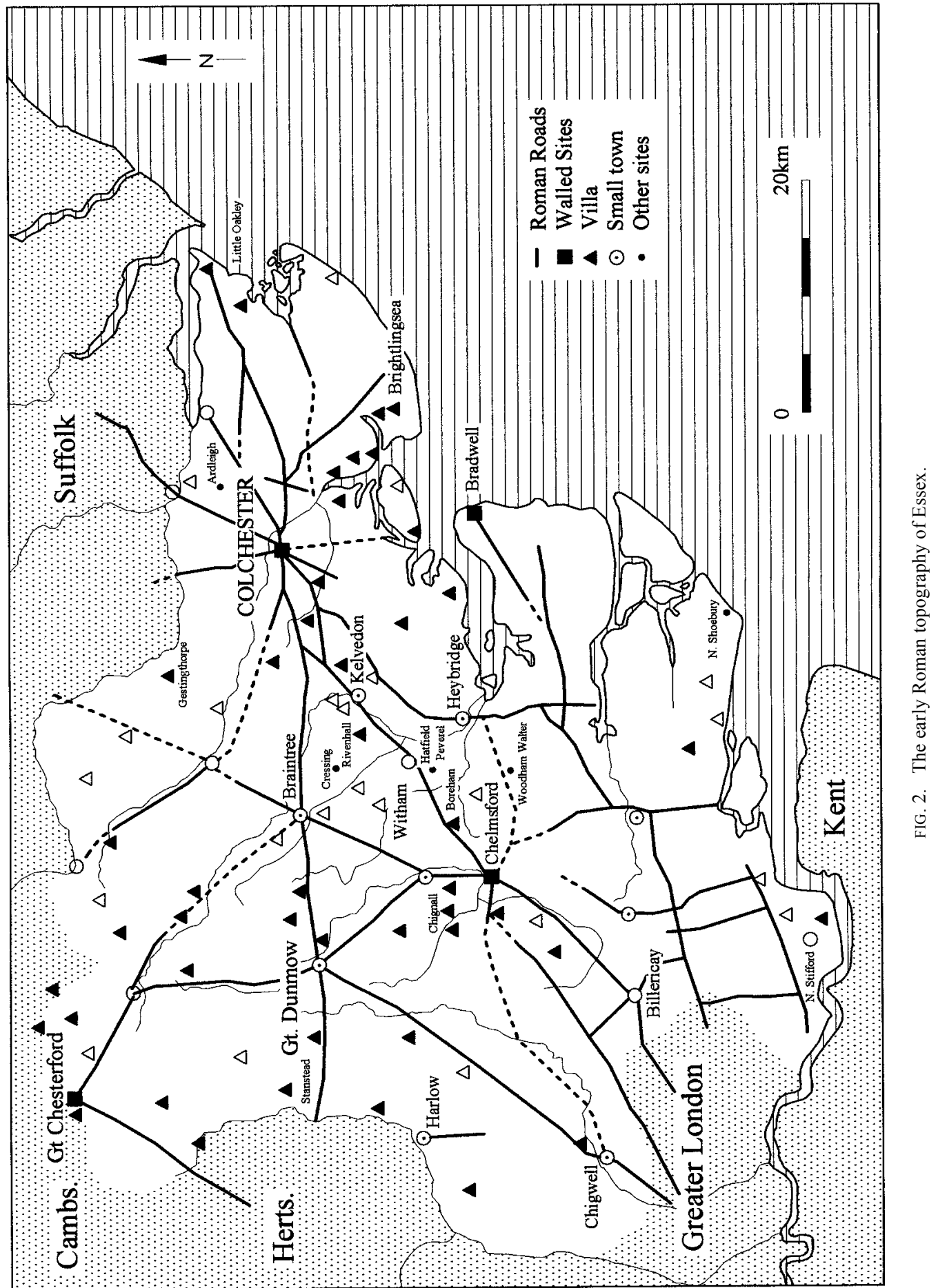


also illustrates the potential of the comparative study of assemblages, quantified by form, from different settlement landscapes. ${ }^{34}$ Clear differences can be established between the types of pottery discarded on different classes of site. The material culture illustrates a range of cultural and economic choices, particularly those involved in display at the dining table. Differing urban and rural lifestyles can be identified from this evidence.

We probably understand the pottery of Roman Essex better than any equivalent region in the Roman world. It has been observed that the "current approach to Roman pottery in Essex offers the greatest opportunity within Britain for achieving major advances in the understanding of urban and rural marketing'. ${ }^{35}$ Given the central importance of pottery in the description of economic and social patterning, this makes Essex one of the most promising areas for study of such patterning in the Roman Empire. A substantial urban sample has been derived from the work in Colchester. Hawkes and Hull produced a type-series from over 40 tonnes of pottery, in addition to a basic tripartite fabric series, with some basic quantification for the occurrence of pottery types in the sequence. ${ }^{36}$ The same sequence was confirmed in the 1970 s with further excavations at Sheepen, with some extension of the basic fabric series published in the mid1980s. ${ }^{37}$ In 1999 the pottery from excavations in Colchester 1971-85 was published. Of the 15,000 tonnes excavated, one third was analysed in detail. ${ }^{38}$ A comparative dating structure can be developed from the ceramic phasing structures used in studies of assemblages from Elms Farm, Heybridge and Chelmsford, supplemented by Late Iron Age and early Roman groups from Kelvedon, Braintree, and Billericay. The rural landscape has seen less by way of synthetic study, but low-status sites are well represented in published but unquantified assemblages. ${ }^{39}$ Concordances established suggest regional ceramic phasing structures. Following the work undertaken on the pottery from Elms Farm, Heybridge, a total of eight regional ceramic phases can be defined to cover the period 50 B.C. to A.D. 260. In this paper, however, we restrict our attention to using some of the ceramic evidence in a smaller case study.

\section{LATE IRON AGE TO ROMAN ESSEX: A PRELIMINARY CERAMIC PERSPECTIVE}

This case-study represents a preliminary attempt to characterise the social and cultural impact of urbanism in Essex in the immediate aftermath of the Roman annexation in A.D. 43. Three sites are considered. The first site is Sheepen, Colchester. ${ }^{40}$ In the Late Iron Age, this site was located at the heart of Colchester's dyke system, with an élite presence indicated by the finds of a mint of Cunobelin and an extensive range of imported fine wares and amphorae. After the conquest, a range of industries was set up (including metalworking, tile and pottery production) presumably to supply the needs of the recently established colonia, within which the second case-study site, Head Street, is located. ${ }^{41}$ The final site is Elms Farm, Heybridge, ${ }^{42}$ a nucleated

\footnotetext{
J. Evans 2001.

Fulford and Huddleston 1991.

Hawkes and Hull 1947.

Niblett 1985.

Symonds and Wade 1999.
}

9 For example in the assessment of potential undertaken for English Heritage, referred to in note 1, 23 large stratified assemblages of the first and second centuries A.D. have been located amidst the published and unpublished archives of excavations undertaken on low-status rural sites in Essex at Stansted, Woodham Walter, Ardleigh, Cressing Temple, Witham (Maltings Lane), North Stifford, and North Shoebury. See also the incomplete review in Condron and Perring 2002, 71-8.

40 Hawkes and Hull 1947; Niblett 1985. The material for analysis in this study comes from Niblett 1985.

41 Brooks and Crummy forthcoming.

42 Atkinson and Preston 1998; forthcoming. 
site with indigenous origins located at the head of the Blackwater estuary. The main objectives of this exercise were to identify signatures of urbanism through the analysis of contextual associations of artefactual data and reconcile these with patterns from non-urban settlements (i.e. Heybridge). Both the sample of sites and quality of available data are necessarily limited at this early stage of research. Nevertheless, it has been possible to demonstrate the existence of significant patterning.

\section{METHODOLOGY}

This section follows a method that has had considerable success in elucidating patterning in Late Iron Age to Roman pottery assemblages within the wider Eastern Kingdom. ${ }^{43}$ There are two stages of analysis. The first examines the relative frequency of the main pottery forms and fabrics at each site by ceramic phase. The second employs correspondence analysis to investigate the depositional profile of the ceramic material.

For the first stage of analysis, quantified pottery groups from the Late Iron Age to early Roman phases at all three sites were converted into tables for comparative analysis by assemblage composition. ${ }^{44}$ Table 1 shows the relative frequency of the main pottery types and generic fabric classes by phase at each site, ${ }^{45}$ and Table 2 shows the relative frequency of the main

\section{TABLE 1. RELATIVE FREQUENCY OF MAIN POTTERY TYPES AT CASE-STUDY SITES IN THE LATE} IRON AGE TO ROMAN TRANSITION

(*The relative incidence of amphorae at Elms Farm is calculated on the basis of sherd weight, not EVE)

$\begin{array}{lllllll}\begin{array}{l}\text { Sheepen, } \\ \text { Colchester }\end{array} & \text { \% Local } & \begin{array}{l}\text { \% Samian } \\ \text { A.D. 5-43 }\end{array} & \begin{array}{l}\text { \% Gallo-Belgic } \\ \text { \% Flagons }\end{array} & \begin{array}{l}\text { \% Mortaria } \\ \text { \% Amphorae }\end{array} \\ \text { A.D. 44-49 } & 60.32 & 7.94 & 19.44 & 0.00 & 0.00 & 2.94 \\ \text { A.D. 49-61 } & 47.41 & 11.12 & 19.98 & 3.57 & 2.78 & 3.97 \\ \text { A.D. 55-61 } & 38.73 & 13.54 & 27.23 & 6.48 & 4.21 & 8.10 \\ \text { Head Street, } & & & & 8.55 & 2.57 & 6.43 \\ \text { Colchester } & \text { \% Local } & \text { \% Samian } & \text { \% Gallo-Belgic } & \text { \% Flagons } & \text { \% Mortaria } & \text { \% Amphorae } \\ \text { A.D. 44-49 } & 71.73 & 2.44 & 3.49 & 12.27 & 5.44 & 4.22 \\ \text { A.D. 49-61 } & 64.05 & 9.99 & 2.31 & 17.40 & 4.39 & 0.71 \\ \text { A.D. 50-70 } & 49.44 & 18.62 & 1.50 & 22.79 & 3.08 & 3.83 \\ \text { Elms Farm, } & & & & & & \text { \% Amphorae } \\ \text { Heybridge } & \text { \% Local } & \text { \% Samian } & \text { \% Gallo-Belgic } & \text { \% Flagons } & \text { \% Mortaria } & \text { \% Am } \\ \text { 50-15 B.C. } & 97.11 & 0.90 & 1.98 & 0.00 & 0.00 & 4.95 * \\ \text { 15 B.C.- A.D. 20 } & 83.32 & 0.05 & 15.34 & 0.27 & 0.02 & 25.23^{*} \\ \text { A.D. 20-55 } & 92.86 & 0.64 & 5.63 & 0.69 & 0.19 & 3.98^{*} \\ \text { A.D. 55-80 } & 93.91 & 2.71 & 0.96 & 1.59 & 0.46 & 1.45^{*}\end{array}$

\footnotetext{
43 Pitts 2005a; 2005b; forthcoming.

44 All the assemblages in this study are dated through a combination of stratigraphic analysis and independent ceramic chronology.

45 Based on Willis 1996.
} 
TABLE 2. RELATIVE FREQUENCY OF MAIN FUNCTIONAL CLASSES OF POTTERY AT CASE-STUDY SITES IN THE LATE IRON AGE TO ROMAN TRANSITION

(*The relative incidence of amphorae at Elms Farm is calculated on the basis of sherd weight, not EVE)

$\begin{array}{lllllll}\text { Sheepen, Colchester } & \text { Quantity } & \text { \% Jars } & \text { \% Drink } & \text { \% Table } & \text { \% Prep/serv } & \text { \% Amph } \\ \text { A.D. 5-43 } & 34 \mathrm{MNV} & 38.24 & 38.24 & 17.65 & 2.94 & 2.94 \\ \text { A.D. 44-49 } & 252 \mathrm{MNV} & 34.01 & 32.39 & 20.24 & 9.31 & 4.05 \\ \text { A.D. 49-61 } & 926 \mathrm{MNV} & 29.53 & 27.36 & 23.02 & 11.94 & 8.14 \\ \text { A.D. 55-61 } & 1322 \mathrm{MNV} & 24.94 & 28.38 & 28.45 & 11.75 & 6.48 \\ \text { Head Street, Colchester } & \text { Quantity } & \mathbf{\%} \text { Jars } & \mathbf{\%} \text { Drink } & \mathbf{\%} \text { Table } & \text { \% Prep/serv } & \text { \% Amph } \\ \text { A.D. 44-49 } & 12.31 \mathrm{EVE} & 51.64 & 15.63 & 8.14 & 20.31 & 4.28 \\ \text { A.D. 49-61 } & 18.22 \mathrm{EVE} & 44.59 & 17.96 & 10.49 & 26.25 & 0.71 \\ \text { A.D. 50-70 } & 26.64 \mathrm{EVE} & 33.86 & 19.68 & 10.97 & 31.64 & 3.85 \\ \text { Elms Farm, Heybridge } & \text { Quantity } & \mathbf{\%} \text { Jars } & \mathbf{\%} \text { Drink } & \mathbf{\%} \text { Table } & \text { \% Prep/serv } & \text { \% Amph } \\ \text { 50-15 B.C. } & 27.85 \mathrm{EVE} & 82.89 & 10.21 & 5.05 & 1.84 & 4.95^{*} \\ \text { 15 B.C.-A.D. 20 } & 62.26 \mathrm{EVE} & 60.12 & 19.62 & 17.52 & 2.74 & 25.23^{*} \\ \text { A.D. 20-55 } & 70.01 \mathrm{EVE} & 65.55 & 16.27 & 13.91 & 4.27 & 3.98^{*} \\ \text { A.D. 55-80 } & 131.51 \mathrm{EVE} & 66.35 & 14.67 & 13.54 & 5.44 & 1.45^{*}\end{array}$

functional classes of pottery by phase at each site. ${ }^{46}$ Details of assemblage size and the means of quantification are also presented in Table 2. Research requires that the evidence of finds be measured and accessible in a way that facilitates comparative analysis. The description of pottery assemblages involves the use of different typologies (especially in the identification of coarse wares) and methods of quantification (as in the inconsistent use of estimated vessel equivalents, or EVEs), compounding the problems generated by the selective approach adopted to decide what to sample, study, and publish. These issues have some bearing on this case-study. Although it was possible to find concordance in the description of vessel forms across all three sites, quantification remains a problem. Material from Elms Farm and Head Street was quantified using EVEs, and the older material from Sheepen had been quantified using minimum number of vessels (or MNVs). Whilst there is no doubt that EVEs are more statistically reliable, ${ }^{47}$ the use of MNVs can nevertheless produce reliable results, provided direct comparisons with EVE data are avoided. In addition, the amphorae at Elms Farm had not been fully quantified by EVE, and their relative incidence in Tables 1 and 2 is expressed in terms of sherd weight. ${ }^{48}$

For the second stage of analysis, stratified ceramic assemblages from each site were interrogated by the statistical technique of correspondence analysis (hereafter referred to as CA). This method is being increasingly deployed in Roman archaeology to discern patterning

46 Based on J. Evans 2001. For the purposes of classification, the term 'table wares' is used here to denote eating vessels such as platters, dishes, and bowls - drinking vessels (e.g. beakers and cups) are classified separately.

47 Orton, Tyers and Vince 1993, 166-81.

48 The problems of quantifying amphorae by EVEs are well documented (Peacock and Williams 1986, 18-19). At Elms Farm, the amphorae were instead quantified by sherd weight. Sherd weight was otherwise not used in this study, owing to our emphasis on the role of vessel form (rather than fabric) in consumption practices (Pitts 2005a; 2005b; forthcoming). 
within and between finds assemblages. ${ }^{49}$ The relevance of CA to this study lies in its ability to compare the finds contents of multiple sites and/or assemblages, by presenting this information in two overlapping visual outputs. The axes of the CA plots essentially measure the amount of variation from the 'average', with the most typical assemblages occurring closest to the plot centre, and the most unusual occurring at the plot extremes as outliers. ${ }^{50}$ The main criterion for the selection of these assemblages was that they were all well-stratified and dated to the period immediately after the Roman conquest. Assemblage size was less important, for a number of reasons. The principal aim of this sort of exercise is to isolate meaningful and representative patterns of contextual association in deposition. Therefore, it does not necessarily follow that 'biggest is best', as large deposits are often not the most representative indicators of everyday depositional practice. Indeed, the current penchant in Roman pottery studies for the analysis of large individual assemblages is ultimately only perpetuating perspectives driven by patterns of perversity.

CA was conducted according to a set of fixed conditions. All the CA plots here are symmetrically scaled. This means that the relationships between directly corresponding assemblages and pottery types can only be assessed relatively, not quantitatively. ${ }^{51}$ To account for this, patterning of note was verified by reference to the original data-sets where the absolute quantities of different pottery types can be obtained for assemblages of interest. ${ }^{52}$ The primary purpose of CA here is to highlight patterns in the deposition of different pottery types by archaeological context, and it is important to stress that it is not intended as a form of absolute statistical testing. Nevertheless, CA was always conducted using the first and second axes, which together account for the most inertia (a figure representing the amount of departure from the average, or the amount of variability in the data).

When conducting CA with a large number of different find-types and assemblages, it is common for patterning in the majority of assemblages to be obscured by the presence of a smaller number of outliers. In this case, the outliers usually comprised smaller assemblages with higher than average proportions of rarer pottery forms. Once the patterning that created the outliers had been accounted for, the results were re-plotted without the outliers to examine trends in the rest of the data. In addition, jar forms, often present in large proportions in most assemblages, were sometimes removed to aid the isolation of patterning in other vessel classes. The process of outlier removal and re-plotting is documented for each site (Appendix 1). The final CA plots (after removal of outliers) are presented in FIGS $3 a-5 b$.

Interpretation of CA plots is as follows. Each set of CA consists of two separate plots - the first showing assemblages separated on the basis of their composition of pottery forms (the numbers denoting archaeological features and contexts), and the second plot showing pottery forms (with extra differentiation for imported fabrics) separated on the basis of their deposition in the different features shown in the first plot. Assemblages with similar pottery composition will cluster together in the first plot, while pottery forms which are frequently found together will cluster together in the second plot. Each area of the first plot directly corresponds to the same area on the second, hence the term 'correspondence analysis'. This allows us to identify which clusters of assemblages are caused by which distinctive sets of pottery forms. In order to aid interpretation in this case-study, the main trends have been directly highlighted on the CA plots. The results of both analysis by assemblage composition and CA are discussed in turn below.

49 Cool, Lloyd-Morgan and Hooley 1995; Lockyear 2000; Cool and Baxter 2002; Biddulph 2005; Pitts 2004; 2005a; 2005b; forthcoming.

50 See Shennan $(1997,308-60)$ for the mathematical underpinning of this technique.

51 Shennan 1997, 324.

52 Full data-sets and details of analysis for this exercise (including removal of outliers from CA) are available in Pitts forthcoming. 
This section provides a chronological summary of ceramic consumption patterns at Sheepen, Head Street, and Elms Farm in the Late Iron Age to Roman transition, and is based upon the results outlined in Tables 1 and 2 . This provides necessary contextual information prior to the CA of the final phase of this sequence in Stage 2.

The earliest stratified pottery groups in this case-study derive from the nucleated site of Elms Farm, Heybridge, dating to the mid- to late first century B.C. The composite assemblage for this period is dominated by locally-produced jar forms (mostly in grog-tempered ware), with very low levels of imports. This situation is consistent with Late Iron Age pottery consumption evident at other contemporary indigenous sites in the wider region, such as Baldock. ${ }^{53}$ However, this picture is quick to change from the Augustan period, c. 15 B.C.-A.D. 20. At Elms Farm, there were significant increases in the proportion of Gallo-Belgic fine wares (i.e. terra rubra and terra nigra), amphorae (mostly Dressel 1), drinking vessels and table wares. These changes in pottery consumption were accompanied by morphological change at the site culminating in the creation of a nucleated and zoned settlement. ${ }^{54}$ In its wider context, this period coincided with the beginnings of a planned settlement at Silchester, the founding of the Skeleton Green-Braughing complex, the deposition of lavishly furnished graves at Welwyn Garden City ${ }^{55}$ and Lexden, Colchester, ${ }^{56}$ and the Romanisation of indigenous coin imagery. ${ }^{57}$ The earliest composite assemblage from Sheepen (dating to $c$. A.D. 5-43) confirms the trends from Elms Farm, with strikingly similar proportions of Gallo-Belgic imports and locally-produced pottery.

The next composite assemblages under consideration date to the period directly following or just encompassing the Claudian conquest (A.D. 44-49 at Sheepen and Head Street, A.D. 20-55 at Elms Farm). At Colchester, the assemblage from the newly imposed fortress at Head Street was characterised by high levels of flagons and mortaria, which were also present for the first time in smaller quantities at Sheepen. Although both sites were notable for high levels of imports in this period, Sheepen continued to receive relatively high proportions of Gallo-Belgic imports, which were scarce at Head Street. In contrast, the composite assemblage from Elms Farm saw a large reduction in Gallo-Belgic imports and amphorae, in addition to lower levels of drinking vessels and table wares. One interpretation of this patterning is that following Roman annexation, the inhabitants of Sheepen were allowed to maintain their status within society, perhaps as Roman clients. This would explain why Sheepen continued to receive large quantities of imports in a period when Elms Farm saw a decline in imports, and also why there exist both qualitative and quantitative differences in ceramic consumption between Sheepen and the official Roman site at Head Street. This model does not easily accord with the published description of postconquest Sheepen as an 'industrial area where a range of products was manufactured for use in the legionary fortress and subsequent colonia at Colchester' ${ }^{58}$ Despite interpretation of the site being hindered by erosion that spared mainly deeper stratigraphic features but very few structural remains, closer analysis of the material from this site suggests that a radical review of traditional explanations is badly needed. ${ }^{59}$

The final period to be considered here is largely Neronian in date, with two overlapping phases for Sheepen (A.D. 49-61 and A.D. 55-61) and Head Street (A.D. 49-61 and A.D. 50-70), and a

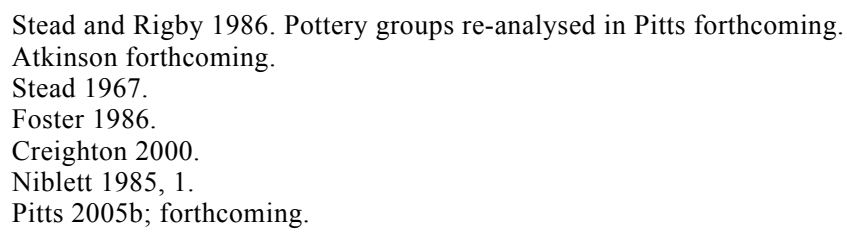


single phase for Elms Farm (A.D. 55-80). The results are largely consistent with the previous period. Elms Farm continued to receive lower levels of imports, although there were notable small increases of samian ware, flagons, and mortaria. In Colchester, increases in samian were also identified at Sheepen and especially Head Street (now, according to Tacitus, designated a colonia), whereas Gallo-Belgic wares continued to increase at Sheepen and decrease at Head Street. Indeed, the extent of disparity in ceramic consumption within Colchester suggests the existence of two separate enclave communities - one indigenous and one colonist. It is at this point that we look to the application of CA to shed further light on this intriguing situation.

\section{STAGE 2: CORRESPONDENCE ANALYSIS}

CA was carried out on all well-stratified pottery assemblages from post-conquest phases at each of the three principal sites in this case-study. The dating and quantity of material from each site is outlined in Table 3. Phases were selected to ensure the best chronological overlap between sites, although this could not be done precisely due to ceramic phasing varying between sites. The results for each site are discussed below.

TABLE 3. DATE RANGES AND QUANTITY OF MATERIAL USED FOR INTRA-SITE ANALYSIS

$\begin{array}{llll}\text { Site } & \text { Date-range } & \text { No. of features } & \text { Quantity of pottery } \\ \text { Sheepen, Colchester } & \text { c. A.D. 55-61 } & 37 & 1322 \mathrm{MNVs} \\ \text { Head Street, Colchester } & \text { c. A.D. 50-70 } & 30 & 26.64 \text { EVEs } \\ \text { Elms Farm, Heybridge } & \text { c. A.D. 55-80 } & 27 & 131.51 \text { EVEs }\end{array}$

\section{Sheepen, Colchester}

Several stratified pottery groups were selected from the Neronian occupation at Sheepen and subjected to CA (FIG. 3). The first feature of note from the CA is the sheer range of imports, including amphorae containing defrutum (fruit syrup), olive oil, fish sauces, and wine, not to mention vessels in Central Gaulish wares (CG), Gallo-Belgic wares such as terra nigra and terra rubra (GB), samian ware (TSG) and other imports (I). Moreover, the imports were found alongside other forms of local origin (pedestal jars, pedestal tazze, and spouted-strainer bowls). The combination of high proportions of imports and local forms evident at Sheepen is particularly difficult to reconcile with the tag of 'Roman industrial site'. However, the most striking pattern from this set of CA plots is the cluster of Gallo-Belgic imports in the lowerright quadrant. The close contextual association of seven vessel forms in the same fine ware fabric is highly significant, and seems to indicate the deliberate deposition of suites of vessels separate from the bulk of other pottery. Moreover, there is a strong implication that imported Gallo-Belgic fine wares and their local imitations were also being used together as drinking and dining sets, perhaps forming a distinctive form of 'native' consumption practice. It is difficult to envisage how such patterning could have been elucidated without using CA.

\section{Head Street, Colchester}

Broadly contemporary material was selected from within the Roman colonia from the recently excavated site at Head Street, Colchester. ${ }^{60} \mathrm{CA}$ of the assemblages from Head Street shows a 
FIG. 3a. CA plot showing features at Sheepen by ceramic composition, c. A.D. 55-61.

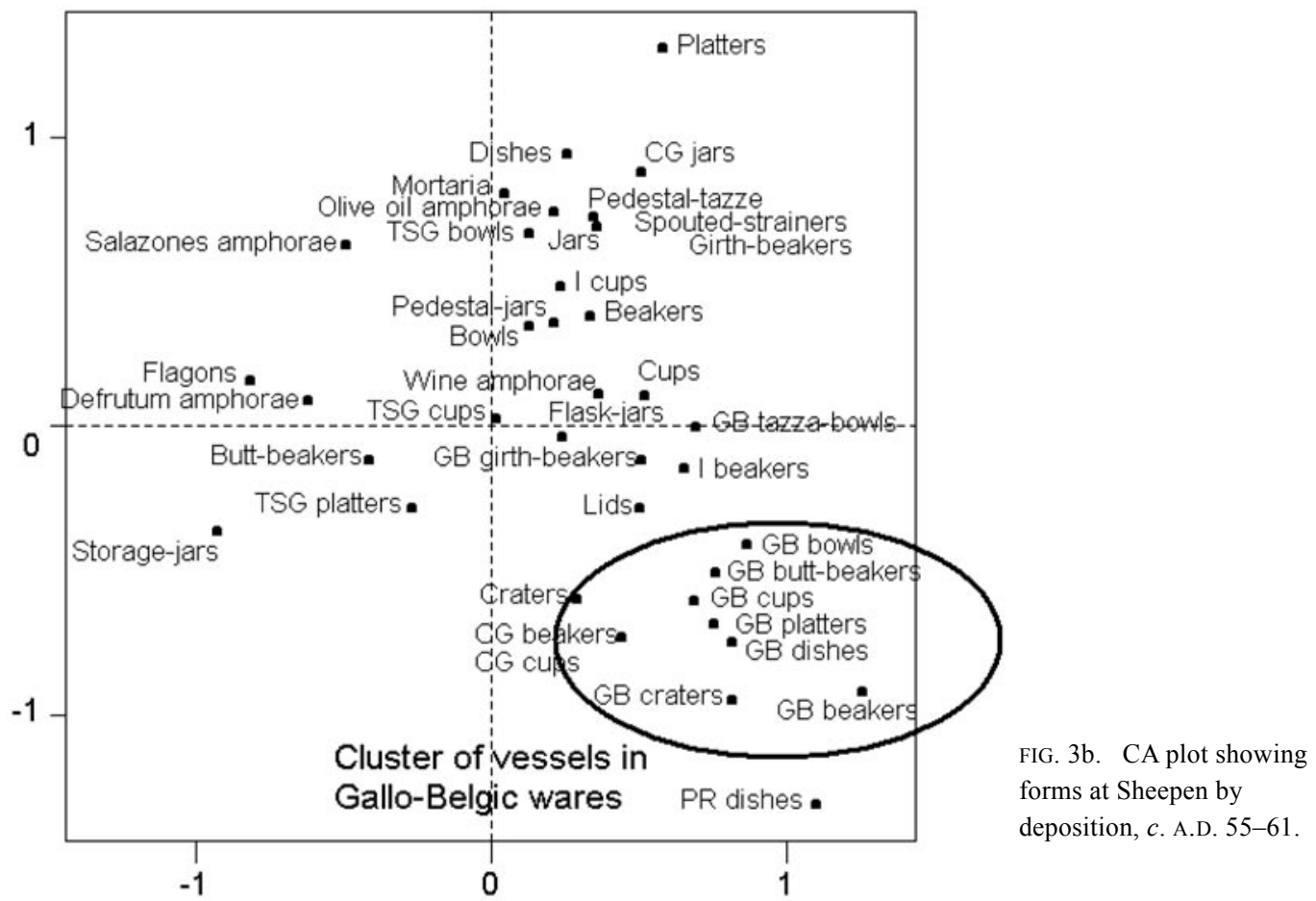


very different picture to that at Sheepen (FIG. 4). The first trend of note is the virtual absence of the Gallo-Belgic fine wares which were so strongly represented at Sheepen, with only a single occurrence in the lower-left quadrant (corresponding to Layer 161). However, as at Sheepen, the most striking pattern consisted of a close association of vessel forms in the same fabric in the upper-right quadrant, again corresponding to a series of pit features. Whereas the cluster at Sheepen was entirely composed of Gallo-Belgic imports, a similar suite of vessels was also apparent at Head Street, this time wholly in samian ware. Again, it is eminently likely that the contextual associations in deposition indicate that samian ware was being used separately from the mass of other pottery forms and fabrics. A telling observation is the close association of this suite of vessels with mortaria, a vessel class with its origins firmly rooted in continental food preparation practices.

The distinctions in ceramic consumption between Sheepen and Head Street have several wide-ranging implications. The clear disparity in supply between the two sites has already been noted in the consideration of assemblage composition. Whereas both sites were receiving large quantities of imports in this period, only Sheepen was receiving Gallo-Belgic fine wares in quantity. Moreover, Sheepen was also receiving significant proportions of distinct, locally-made vessels such as pedestal jars and butt-beakers, which were almost completely absent from Head Street. This patterning certainly does not fit comfortably with the idea that Sheepen was a Roman industrial site serving the needs of the colonia, and suggests it is inherently more likely to have formed part of a separate 'native' community with strong links to the Continent. It is within this framework that the disparity in ceramic deposition between the two sites can be approached, with complete suites of Gallo-Belgic fine wares being favoured at Sheepen and suites of samian vessels being preferred at Head Street.

The reason for the apparent favouring of different sets of fine-ware pottery would appear to lie in the slightly different functional emphasis in the respective repertoires of Gallo-Belgic and samian vessel forms. Given that the Gallo-Belgic pottery industry was largely based on the imitation of arretine samian, ${ }^{61}$ it is not surprising that a large proportion of forms in samian ware (e.g. bowls, cups, dishes, and platters) had direct equivalents in the Gallo-Belgic series of vessels at Colchester. However, there remain some critical differences, most notably the larger butt-beakers and girthbeakers in Gallo-Belgic fabrics, which were also being produced and copied in quantity by local potters throughout South-East England in this period. Drinking vessels of this shape are without obvious parallel in mid-first-century samian assemblages in the region, and the provision of largecapacity drinking vessels represents the major difference between the samian suites at Head Street and the Gallo-Belgic suites at Sheepen. This ties in nicely with evidence for the significance of 'native' beer (as opposed to Roman wine) in indigenous strategies for consumption and social display, which would have required larger vessels for the intoxicating effects to be felt. ${ }^{62}$

If the occupants of Sheepen formed part of a 'native' faction, it is not surprising that they would favour a suite of fine ware vessels which was closer in functional terms to native pottery (which clearly favours the production of large drinking vessels such as butt-beakers and pedestal jars). The trend of depositing similar combinations of complete Gallo-Belgic imported vessels is especially notable in middle- to high-status graves elsewhere in Essex, such as at Birchanger, ${ }^{63}$ Colchester (Lexden ${ }^{64}$ and Stanway ${ }^{65}$ ), Little Waltham, ${ }^{66}$ and Southend, ${ }^{67}$ where full suites of

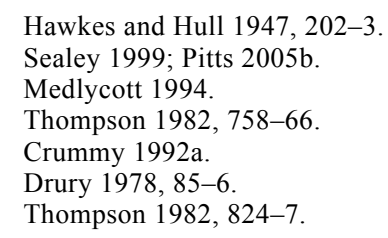


FIG. 4a: CA plot showing features at Head Street by ceramic composition, $c$. A.D. 50-70.

FIG. 4b. CA plot showing forms at Head Street by deposition, c. A.D. 50-70. 
Gallo-Belgic imports are apparent. Therefore, both domestic and funerary assemblages seem to point towards Gallo-Belgic vessels being used in status drinking and dining kits, being differentiated from samian ware through the provision of a greater range of drinking forms than table wares. Moreover, it is likely that this patterning represents the need of the native population to affirm their own identities in a period when their grip on power was waning. The idea of indirect competitive consumption between the old LPRIA aristocracy at Sheepen and the new colonist entity at Head Street is particularly appealing.

\section{Elms Farm, Heybridge}

The final site to be subjected to CA was Elms Farm, Heybridge (FIG. 5). Despite the lower quantity and variety of imports relative to Sheepen, there are a number of similarities in ceramic consumption and deposition between the latter and Heybridge. Both sites were characterised by significant quantities of locally-made forms (from the common butt-beaker to the rarer pedestaltazza) in addition to imported fine wares in both samian and Gallo-Belgic fabrics. However, the patterning of most significance is the depositional profile of this material. Whereas the samian vessel forms were seemingly scattered in different features, the very small proportion of Gallo-Belgic imports (beakers, butt-beakers, and platters) and locally-produced beakers and butt-beakers were all plotted in close proximity, corresponding to the biggest cluster of features. Despite the small quantities of Gallo-Belgic imports at the site in this period (Table 1), the deposition patterning of this material hints at similar practices to those taking place at Sheepen - a trait confirmed in CA of the previous phase at Elms Farm. ${ }^{68}$ This implies that the distinctive patterning at Sheepen was not unique to the site, but instead was rooted in indigenous practices witnessed elsewhere in the region.

\section{DISCUSSION}

The exercise described above shows how the different patterns of consumption seen in the pottery assemblages illustrate different social practices. These help distinguish between an urbanising élite that antedated the Roman conquest, and the colonists that arrived in the wake of the Claudian conquest.

It seems likely that sometime following the Caesarian expedition of 54 B.C. the region had become a Roman client kingdom. In particular the changes identified in the archaeological record dating from the period c. 25-15 B.C. witness something akin to an Augustan cultural revolution, taking place beyond the territories directly annexed by Rome. The invasion of A.D. 43 eventually resulted in the imposition of a more discernibly alien entity, involving soldiers and veterans supported by supply and contact directed along the Rhine frontier. Colchester was therefore host to two co-existing patterns of display and consumption — the 'Gallo-Belgic' or 'Gallo-Roman' patterns formed prior to conquest, alongside newer tastes which derived from practices developed along the German frontier. ${ }^{69}$ These different patterns of social display were socially and spatially distinct, but occupied contiguous spaces. It is a salutary reminder of the way in which the distribution patterns of goods that are likely to have been offered for sale can reflect more on socially-embedded cultural values than on economic forces. This situation was

\footnotetext{
68 Pitts forthcoming. CA of assemblages dated to $c$. A.D. 20-55 at Elms Farm revealed similar patterning to that at Sheepen.

69 See J. Evans 2005 for the parallels he draws between the Gallo-Roman assemblages of the British oppida and sites in the Aisne valley, and Caroll 2004 for the way in which spatially distinct Roman and native communities were also involved in the early urbanisation of the Rhine frontier itself.
} 
FIG. 5a. CA plot showing features at Elms Farm by ceramic composition, $c$. A.D. 55-80.

FIG. 5b. CA plot showing forms at Elms Farm by deposition, c. A.D. 55-80. 
short-lived, with Gallo-Belgic patterns of display falling out of favour following the revolt of A.D. 60/1 and Gallo-Belgic pottery completely declining before the end of the first century A.D.

This description of alien social practices and patterns of consumption attending the foundation of a new city was not unique to the colony at Colchester. Indeed, something rather similar has been argued for the Late Iron Age urban site at Silchester where 'the evidence from Calleva is reminiscent of that from the early Greek colonies in the west Mediterranean and it is not, perhaps, inappropriate to conceive of the settlement as a colony which is principally populated by an immigrant group from Gaul' ${ }^{70}$ Rather than see these sites as unusual, there are grounds for proposing that it is probable that the majority of urban sites of both the Late Iron Age and early Roman phases of settlement were essentially immigrant communities. This was certainly the case for Roman London, which was affiliated to the needs of the imperial administration. ${ }^{71}$ Parallels can also be drawn with the Roman site at Wroxeter. This offers another instance of a 'perverse' relationship between town and country, and raises the possibility that such relations were the norm for imposed urban centres. Other major centres such as York have highly specific ceramic assemblages that differ from those found at other sites in their regions, which appear to have retained a strong degree of indigenous culture. ${ }^{72}$ These urban centres can all be cast as 'cultural islands', ${ }^{73}$ and indeed, it is difficult to escape the conclusion that 'the Roman way of life, and the cultural material that went with it, was largely considered an irrelevance by those living outside the city walls'. ${ }^{74}$

The importance of Camulodunum needs to be evaluated against a range of alternative centres. Power was not exclusively urban. The picture of a landscape studded by Claudian and Neronian forts is now largely rejected. ${ }^{75}$ In Essex the only military establishments that seem likely to belong to the period A.D. 43-61 are the fortress at Colchester and the supply base at Fingringhoe. Both may have been attached to pre-existing Iron Age sites. Many other aspects of the settlement pattern within Southern Britain also originated in the Late Iron Age. This is particularly evident in the distribution and organisation of the minor nucleated sites commonly known as 'small towns'. There are dangers in assuming that this class of site represents a uniform phenomenon, and one of the purposes of the research in progress is to test existing classificatory systems by independently describing sites according to the character of their archaeological assemblages.

It is clear, however, that several 'small towns' of the Eastern Kingdom had become important seats of power in the Late Iron Age. Elms Farm, Heybridge is a useful example. ${ }^{76}$ The morphology of the Roman settlement here derived directly from the Late Iron Age site. This was laid out around a central 'ritual' site where a temple was later built. The reorganisation of this settlement c. 25-15 B.C., in conjunction with the evidence of imported suites of ceramics and possible élite feasting activities, ${ }^{77}$ suggests that the site may even have been conceptualised as an urban foundation in the pre-conquest period. However, the decline in imported pottery

\footnotetext{
Fulford and Timby 2000, 563.

Perring 1991, 13-14.

Monaghan 1997. See also J. Evans 2005, 160.

Another characteristic of many of these early urban foundations is the way that they were located on or close to the boundaries of what we know of the polities that they supposedly controlled. The clearest examples are London on the Thames, Wroxeter on the Severn, and York on the Ouse. These river systems seem likely to have formed boundaries between polities annexed by Rome. Colchester and Silchester were also located suggestively close to the north-east boundaries of the coin systems within which they fell (Fulford and Timby 2000, 558). Parallels can, of course, be drawn with Rome itself (on the boundary between Latin and Sabine), Lyon, and a host of other major Roman cities. The point here is that such locations lend themselves to immigrant plantations.

74 White and Gaffney 2003, 231.

75 Millett 1990.

76 Atkinson and Preston 1998, 92.

77 Pitts 2004.
} 
at the site around the time of the conquest hints at the reordering of social power in the wider settlement hierarchy following the Claudian annexation. Indeed, the floruit of Gallo-Belgic imports at the polyfocal complex of Colchester (including sites such as Sheepen and Stanway) coincides with the decline of the fabric at Elms Farm and several other indigenous sites in the region beyond Colchester's orbit. ${ }^{78}$ It is likely that such patterning represents early evidence of Rome's appropriation and exploitation of the existing settlement hierarchy.

The political and economic role of secondary sites similar to Heybridge ${ }^{79}$ merits further attention. In the Late Iron Age, the distribution of these sites across the Eastern Kingdom suggests that the political structure of this territory involved a series of separate lineages or septs. ${ }^{80}$ Distribution plots of coins bearing potential names of rulers can also help indicate sub-tribal areas and centres of political power towards the end of the Iron Age. For example, plots of issues of Dias, Rues, and Andoco indicate the prominence of Rues at Sandy, Andoco at Baldock, and Dias at Braughing. ${ }^{81}$ However, the role of these sites in the generations after the conquest remains uncertain. It is widely assumed that these lesser nucleated centres functioned as markets. In the recent interim report on the work at Elms Farm, Heybridge it is argued that the site 'had a dual function as a point of collection and supply of agricultural produce to regional centres and as a service centre for the local community'. ${ }^{82}$ But as with the larger oppida, it is not at all clear that this was the case.

\section{FUTURE DIRECTIONS}

The emphasis in this paper has been on consumers not producers, and on social patterns of consumption rather than the economic circumstances which enabled consumer behaviour and through which social power was maintained. Our description of the social origins of Britain's first cities leaves open the question of how these places were supported, and what their economic role and function might have been. Many of those involved in the archaeological study of Late Iron Age and early Roman nucleated sites believe that they were market-places serving the needs of local farmers, although it is recognised that this may have been a later development at sites which had earlier social and ritual functions. ${ }^{83}$ The recent survey based on mapping the economic impact of Wroxeter also assumes that towns served as markets, and were surrounded by second-order settlements in accordance with Central Place Theory. White and Gaffney argue that the pattern of urban settlement in Roman Britain appears consistent with Central Place Theory, and their survey of the Wroxeter hinterlands was designed to measure the 'local, market-led, impact on the local populace, as reflected in the dispersal from the town of products purchased in its markets' ${ }^{84}$

Jerry Evans has recently presented a forceful argument in favour of seeing towns as markets. ${ }^{85}$ It is undeniable that many goods reached urban consumers through shops and markets. What is not so clear is how these goods reached the shops and markets found in towns. Although

78 Pitts forthcoming.

79 A series of other 'small towns' has been found in Essex (Billericay, Braintree, Chelmsford, Witham, Great Dunmow, Great Chesterford, and Kelvedon), Hertfordshire (Sandy, Baldock, and Braughing), and Kent (e.g. Springhead). Most of these sites, like that at Heybridge, were religious and political centres first established during the Late Iron Age.

80 Millett 1990.

81 Mark Curteis pers. comm.

82 Atkinson and Preston 1998, 92.

83 Williams 2003, 221; Atkinson and Preston 1998, 107.

84 White and Gaffney 2003, 221.

85 J. Evans 2005. 
merchants are known to have organised urban supply, it is also clear that the transportation systems and commercial infrastructures that they drew upon benefited from the command economies of the Roman state and army. It is also the case that patterns of urban consumption were not carried through into surrounding territories, such that rural communities located on the outskirts of shop-ridden cities owned few of the goods available in these shops. If country folk went to town for market, they were disinclined to return home with the consumer durables that archaeologists can study. Towns contained markets, but seen from the countryside they may not have been markets.

This leads us to the question - can we describe and understand markets from archaeological evidence? This is not straightforward. The assumption that towns were significant markets needs to be tested. Research requires a detailed investigation of access to imported, regionally and locally produced ceramics. However, pottery is far from the only source of information available. Faunal assemblages can also be used to characterise 'Romanised' and 'native' animal husbandry practices and diet, ${ }^{86}$ whilst the potential of other classes of finds, in particular small finds, is being realised in a series of thematic and regional surveys. ${ }^{87}$ These are all sources of information that we wish eventually to address in our research. Here we hope to have demonstrated that the reinterpretation of excavated assemblages has enormous potential, and that this data can be put in service of a series of challenging research questions.

\section{APPENDIX 1: THE REMOVAL OF OUTLIERS FOR CORRESPONDENCE ANALYSIS}

FIG. 3: Features 213/220, L3, 339, 132, 303, and 247 were removed from the initial CA plot. In sum, these features accounted for $44 \mathrm{MNV}$, representing 3.3 per cent of the total period assemblage outlined in Table 3.

FIG. 4: Features L583, L187, F246, F276, F454, F243, F810, and L177 were removed from the initial CA plot. In sum, these features accounted for 2.59 EVE, representing 9.7 per cent of the total period assemblage outlined in Table 3. Olive oil amphorae and jars were also removed to aid the identification of patterning in other vessel classes.

FIG. 5: Features 6646, 4163, 9084, 17086, 10055, 11602, 9213, 13771, 19176, and 20174 were removed from the initial CA plot. In sum, these figures accounted for 26.12 EVE, representing 19.9 per cent of the total period assemblage outlined in Table 3. Jars were also removed to aid the identification of patterning in other vessel classes.

\section{ACKNOWLEDGEMENTS}

This paper incorporates data and ideas from many sources. We owe particular thanks to Patrick Allen, Mark Atkinson, Howard Brooks, Joyce Compton, Frances Condron, Hilary Cool, John Creighton, Nina Crummy, Philip Crummy, Mark Curteis, Chris Evans, Jerry Evans, Hella Eckardt, Chris Going, Richard Hingley, Scott Martin, Maria Medlycott, Steve Roskams, Chris Scull, Paul Sealey, Jane Timby, Angela Wardle, Leo Webley, Mark Whyman, Nick Wickendon, Tim Williams, and Steve Willis. We are also grateful to both English Heritage and the Arts and Humanities Research Council for their funding of various aspects of the research.

University College London

mejp101@yahoo.co.uk

d.perring@ucl.ac.uk

87 Crummy and Eckardt 2003. 


\section{BIBLIOGRAPHY}

Atkinson, M. forthcoming: 'Settlement morphology', in M. Atkinson and S.J. Preston, Elms Farm: Excavations at the Late Iron Age and Roman Site at Heybridge, Essex, 1993-5, East Anglian Archaeology Report, Chelmsford

Atkinson, M., and Preston, S.J. 1998: 'The Late Iron Age and Roman settlement at Elms Farm, Heybridge, Essex, excavations 1993-5: an interim report', Britannia 29, 85-110

Atkinson, M., and Preston, S.J. forthcoming: Elms Farm: Excavations at the Late Iron Age and Roman Site at Heybridge, Essex, 1993-5, East Anglian Archaeology Report, Chelmsford

Biddulph, E. 2005: 'Last orders: choosing pottery for funerals in Roman Essex', Oxford Journal of Archaeology 24, 23-45

Brooks, H., and Crummy, P. forthcoming: 29-39 Head Street, Colchester: 2000 Excavations, Colchester

Carrol, M. 2004: 'The genesis of Roman towns on the Lower Rhine', in P. Wilson (ed.), The Archaeology of Roman Towns, Exeter, 22-30

Castells, M. 1977: The Urban Question: A Marxist Approach, London

Condron, F., with Perring, D. 2002: 'Iron Age to Roman', in D. Perring, Town and Country in England: Frameworks for Archaeological Research, York, 69-81

Cool, H.E.M., and Baxter, M.J. 2002: 'Exploring Romano-British finds assemblages', Oxford Journal of Archaeology 21, 365-80

Cool, H.E.M, Lloyd-Morgan, G., and Hooley, A.D. 1995: Finds from the Fortress. The Archaeology of York, The Small Finds 17/10, York

Creighton, J. 2000: Coins and Power in Late Iron Age Britain, Cambridge

Crummy, N., and Eckardt, H. 2003: 'Regional identities and technologies of the self: nail-cleaners in Roman Britain', Arch. Journ. 160, 44-69

Crummy, P. 1984: Excavations at Lion Walk, Balkerne Lane and Middleborough, Colchester, Essex, Colchester Archaeological Report 3, Colchester

Crummy, P. 1992a: 'Aristocratic graves at Colchester', Current Archaeology 132, 492-7

Crummy, P. 1992b: Excavations at Culver Street, the Gilberd School, and Other Sites in Colchester 19711985, Colchester Archaeological Report 6, Colchester

Crummy, P. 1997: Colchester, Colchester

De Jersey, P. 2001: 'Cunobelin's silver', Britannia 32, 1-44

Down, A., and Rule, M. 1971: Chichester Excavations 1, Chichester

Down, A. 1989: Chichester Excavations 6, Chichester

Down, A. 1993: 'The Theological College 1985 and 1987', in A. Down (ed.), Chichester Excavations 8, Chichester

Drury, P.J. 1978: Excavations at Little Waltham 1970-71, CBA Research Report 26, Chelmsford

Evans, C. 2003: 'Britons and Romans at Chatteris: investigations at Langwood Farm, Cambridgeshire', Britannia 34, 175-264

Evans, J. 2001: 'Material approaches to the identification of different Romano-British site types', in S. James and M. Millett (eds), Britons and Romans: Advancing an Archaeological Agenda, CBA Research Report 125, York, 26-35

Evans, J. 2005: 'Pottery in urban Romano-British life', in A. MacMahon and J. Price (eds), Roman Working Lives and Urban Living, Oxford, 145-66

Foster, J. 1986: The Lexden Tumulus: a Re-appraisal of an Iron Age Burial from Colchester, Essex, British Archaeological Reports British Series 156, Oxford

Fulford, M.G. 1975: New Forest Roman Pottery, British Archaeological Reports British Series 17, Oxford

Fulford, M.G. 2003: 'Julio-Claudian and early Flavian Calleva', in P. Wilson (ed.), The Archaeology of Roman Towns, Exeter, 95-104

Fulford, M.G., and Huddleston, K. 1991: The Current State of Romano-British Pottery Studies, EH Occ. Pap.

Fulford, M.G., and Timby, J. 2000: Silchester: Excavations on the Site of the Forum-Baslica, 1977, 1980 86, Britannia Monograph 15, London

Haselgrove, C.C. 1982: 'Wealth, prestige and power: the dynamics of Late Iron Age political centralisation in South-East England', in C. Renfrew and S. Shennan (eds), Ranking, Resource and Exchange, Cambridge and New York, 79-88 
Haselgrove, C.C., and Millett, M. 1997: 'Verulamium reconsidered', in A. Gwilt and C.C. Haselgrove (eds), Reconstructing Iron Age Societies, Oxbow Monographs 71, 282-96

Hawkes, C.F.C., and Crummy, P. 1995: Camulodunum 2, Colchester Archaeological Report 11, Colchester

Hawkes, C.F.C., and Hull, M.R. 1947: Camulodunum. First Report on the Excavations at Colchester 1930-39, Rep. Res. Comm. Soc. Antiq. 14, London

Hill, J.D. 2001: 'Romanisation, gender and class: recent approaches to identity in Britain and their possible consequences', in S. James and M. Millett (eds), Britons and Romans: Advancing an Archaeological Agenda, CBA Research Report 125, York, 12-18

Hill, J.D., Evans, C., and Alexander, M. 1999: 'The Hinxton Rings: a Late Iron Age cemetery at Hinxton, Cambridgeshire, with a reconsideration of northern Aylesford-Swarling distributions', Proc. Prehistoric Soc. $65,243-74$

Jacobs, J. 1969: The Economy of Cities, New York

King, A.C. 1991: 'Food production and consumption - meat', in R.F.J. Jones (ed.), Roman Britain: Recent Trends, Sheffield, 15-20

Lockyear, K. 2000: 'Site finds in Roman Britain: a comparison of techniques', Oxford Journal of Archaeology 19, 397-423

Magilton, J. 2003: 'The defences of Roman Chichester', in P Wilson (ed.), The Archaeology of Roman Towns, Exeter, 156-67

Mattingly, D.J. 2004: 'Being Roman: expressing identity in a provincial setting', Journal of Roman Archaeology 17, 5-25

Medlycott, M. 1994: 'Iron Age and Roman material from Birchanger', Essex Archaeology and History 25, 28-45

Mieroop, M. van de, 1999: The Ancient Mesopotamian City (2nd edn), Oxford

Millett, M. 1990: The Romanization of Britain: An Essay in Archaeological Interpretation, Cambridge

Niblett, R. 1985: Sheepen: An Early Roman Industrial Site at Camulodunum, CBA Research Report 57, London

Monaghan, J. 1997: Roman Pottery from York, York

Orton, C.R., Tyers, P.A., and Vince, A. 1993: Pottery in Archaeology, Cambridge

Parkins, H. (ed.) 1997: Roman Urbanism: Beyond the Consumer City, London and New York

Peacock, D.P.S., and Williams, D.F. 1986: Amphorae and the Roman Economy, London

Perring, D. 1991: Roman London, London

Perring, D. 2002a: The Roman House in Britain, London

Perring, D. 2002b: Town and Country in England: Frameworks for Archaeological Research, CBA Research Report 134, York

Petts, D. 2002: 'Votive hoards in late Roman Britain: pagan or Christian?', in M.O.H. Carver (ed.), The Cross Goes North. The Age of Conversion in Northern Europe, AD 300-1300, York, 109-18

Pitts, M. 2004: “I drink, therefore I am?” Pottery consumption and identity at Elms Farm, Heybridge, Essex', in B. Croxford, H. Eckardt, J. Meade and J. Weekes (eds), TRAC 2003. Proceedings of the Thirteenth Annual Theoretical Roman Archaeology Conference, Leicester 2003, Oxford, 16-27

Pitts, M. 2005a: 'Regional identities and the social use of ceramics', in J. Bruhn, B. Croxford and D. Grigoropoulos (eds), TRAC 2004. Proceedings of the Fourteenth Annual Theoretical Roman Archaeology Conference, Durham 2004, Oxford, 50-64

Pitts, M. 2005b: 'Pots and pits: drinking and deposition in late Iron Age South-East Britain', Oxford Journal of Archaeology 24, 143-61

Pitts, M. forthcoming: Consumption and Identity in Essex and Hertfordshire, c. 50 B.C.-A.D. 200: a Ceramic Perspective, unpub. $\mathrm{PhD}$ thesis, University of York

Rivet, A.L.F. 1964: Town and Country in Roman Britain (2nd edn), London

Rykwert, J. 1976: The Idea of a Town: the Anthropology of Urban Form in Rome, Italy and the Ancient World, London

Sealey, P.R. 1999: 'Finds from the cauldron pit. The spouted strainer bowls', in N.R. Brown, The Archaeology of Ardleigh, Essex: Excavations 1955-1980, East Anglian Archaeology Report 90, Chelmsford, 117-24

Sealey, P.R. forthcoming: ‘Amphoras', in M. Atkinson and S.J. Preston, Elms Farm: Excavations at the Late Iron Age and Roman Site at Heybridge, Essex, 1993-5, East Anglian Archaeology Report, Chelmsford 
Shennan, S. 1997: Quantifying Archaeology, Edinburgh

Stead, I.M. 1967: ‘A La Tène III burial at Welwyn Garden City', Archaeologia 101, 1-62

Stead, I.M., and Rigby, V.A. 1986: Baldock: the Excavation of a Roman and Pre-Roman Settlement, 1968-72, Britannia Monograph 7, London

Symonds, R.P., and Wade, S. 1999: Roman Pottery from Excavations in Colchester, 1971-86, Colchester Archaeological Report 10, Colchester

Thompson, I. 1982: Grog-tempered 'Belgic' Pottery of South-Eastern England, BAR British Series 108, Oxford

Wacher, J.S. 1995: The Towns of Roman Britain (2nd edn), London

Webster, G. (ed.) 1988: Fortress into City. The Consolidation of Roman Britain, First Century AD, London

White, R.H., and Gaffney, V.I. 2003: 'Resolving the paradox: the work of the Wroxeter Hinterlands Project', in P. Wilson (ed.), The Archaeology of Roman Towns, Exeter, 221-32

Whittaker, C.R. 1990: 'The consumer city revisted: the vicus and the city', Journal of Roman Archaeology $3,110-18$

Whittaker, C.R. 1995: 'Do theories of the ancient city matter?', in T.J. Cornell and K. Lomas (eds), Urban Society in Roman Italy, London, 9-26

Williams, J.H. 2003: 'New light on Roman Kent', Journal of Roman Archaeology 16, 219-36

Willis, S. 1996: 'The Romanization of pottery assemblages in the East and North-East of England during the first century A.D.: a comparative analysis', Britannia 27, 179-221 